\title{
An Improved Method of Analysis of Uranium in Sea Water Using Chelating Resin
}

\author{
Yukio Sugimura* and Masaru Mayeda** \\ * Meteorological Research Institute, Tsukuba, Japan \\ ** Tokyo University of Fisheries, Konan, Minato, Tokyo 108, Japan
}

(Received May 8, 1981)

\begin{abstract}
A more rapid and precise method than hitherto of determining uranium in sea water is described. The separation of uranium is done by adsorption on chelating resin in weak acid media with equilibrium batch method instead of chromatographic method as previously used. The determination of uranium is done by alpha-spectrometric method using ${ }^{232} \mathrm{U}$ tracer and spectrophotometric method using uranyl-Arsenazo complex. The average recovery by this improved method is $100 \%$ and the standard deviation of the analytical result is below $2 \%$.
\end{abstract}

\section{Introduction :}

During the study of marine geochemistry of uranium in our laboratory, rapid and accurate methods of analysis to be used aboard a ship, combined with a method of isolation of uranium with chelating resin have been developed. Of these methods, the spectrophotometric method after chromatographic separation of uranium by means of chelating resin was as reported previously (Miyake et al., 1966, 1970, 1972). As mentioned in the previous reports, the chelating resin is one of the simplest methods for the determination of uranium in sea water.

In this report, the present authors intend to describe some improvements in the determination of uranium in sea water in which the isotope dilution and spectrophotometry after the liquid-solid extraction by chelatihg resin are used. These methods have been used practically for shipboard analysis of uranium during the Pacffic Expeditions (19681972), which were conducted by the Ocean Researdh Institute, University of Tokyo, on board the R.V. Hakuho-maru.

\section{Analytical methods:}

The necessary reagents in these methods are as follows: Chelating resin (Dowex A-1 or Biolad Chelex 100), 50 to 100 mesh ; Dowex $1 \times 8$ (50 to $100 \mathrm{mesh}) ;{ }^{232} \mathrm{U}$ as a tracer and $0.05 \%$ Arsenazo-III solution.

The standard solution of uranium was prepared by dissolving $\mathrm{U}_{3} \mathrm{O}_{8}$ of high purity in $1 \mathrm{M} \mathrm{HNO}_{3}$.

For the standard of radioactivity of uranium, the uraninite which was produced in the Schwartzwalder mine in the U.S.A. was used in which the activity ratio of ${ }^{234} \mathrm{U} /{ }^{238} \mathrm{U}$ was $0.995 \pm 0.021$.

The alpha-spectrum intensities of ${ }^{234} \mathrm{U}$ (4.77, $4.72 \mathrm{MeV}),{ }^{238} \mathrm{U}(4.20,4.15 \mathrm{MeV})$ and ${ }^{232} \mathrm{U}(5.32,5.27 \mathrm{MeV})$ were measured with an alpha-ray spectrometer consisting of a solid state detector connected with a multichannel pulse height analyzer.

For the spectrophotometric determination, a spectrophotometer having a long cell (50 to $100 \mathrm{~mm}$ ) was used.

\subsection{Determination of uranium:}

(A) The simultaneous determination of the content of uranium and the activity ratio 
of ${ }^{234} \mathrm{U} /{ }^{238} \mathrm{U}$ by means of the isotope dilution method.

The separation of uranium was carried out by adsorption on chelating resin in weak acid media with equilibrium batch method. After adding a known amount of ${ }^{232} \mathrm{U}$ tracer (10 to $20 \mathrm{dpm}$ ) to 3 to 5 liters of sea water, the solution was acidified to $\mathrm{pH} 3$ with $6 \mathrm{M}$ $\mathrm{HCl}$ and stood for one hour under continuous stirring. And then $1 \mathrm{ml}$ of chelating resin (Dowex A-1 or Chelex 100) was added to 1 liter of sea water, and the mixture was stirred for 10 to 15 hours.

The resin on which uranium was adsorbed was collected into a chromatographic column, and it was washed with $500 \mathrm{ml}$ of dilute $\mathrm{HCl}$ solution of $\mathrm{pH} 3$. Uranium was subsequently eluted with $250 \mathrm{ml}$ of $5 \mathrm{M} \mathrm{HCl}$ and the effluent was evaporated to dryness.

The residue was dissolved in a small amount of $10 \mathrm{M} \mathrm{HCl}$ and further purification was done by anion exchange resin (Dowex $1 \times 8$ of $\mathrm{Cl}^{-}$form, 50 to 100 mesh). Uranium was eluted with $0.1 \mathrm{M} \mathrm{HCl}$ and the effluent was dried up on a hot plate. A trace of iron which interferes with the alpha-spectrometry of uranium was removed by the extraction with isopropyl ether from the media of $8 \mathrm{M} \mathrm{HCl}$, an aqueous layer was again evaporated to dryness.

For the alpha-spectrometric determination, the residne was dissolved in $1 \mathrm{ml}$ of $1 \mathrm{M} \mathrm{HCl}$ and transferred to an electroplating unit with $20 \mathrm{ml}$ of ethyl alcohol (Kim et al., 1966). Uranium isotopes were then electroplated on a cathode made of a silver disk $(3 \mathrm{~cm}$ in dia. and $0.05 \mathrm{~mm}$ thick) for 2 hours with direct current of $15 \mathrm{~V}$ and $200 \mathrm{~mA}$.

Typical alpha-spectrum of uranium isotopes is shown in Fig. 1. In converting the activity of ${ }^{238} \mathrm{U}$ into a weight, a half-life of ${ }^{238} \mathrm{U}$ of $4.51 \times 10^{9} \mathrm{y}$ and an abundance ratio of 0.9928 were used.

(B) Spectrophotometric method.

Though the new method is essentially the same in principle as that reported previously by the present authors (Miyake et al., 1966, 1970, 1972). but some modifications

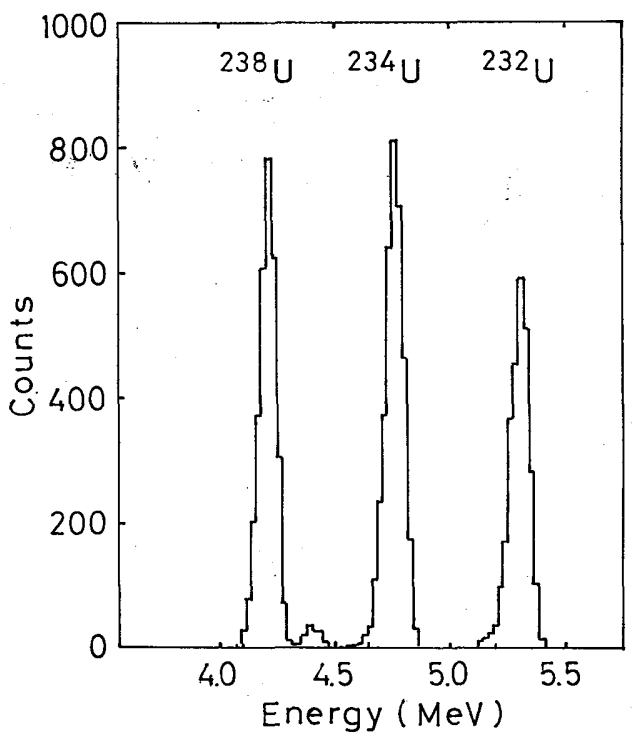

Fig. 1. Alpha-spectrum of naturally occurring uranium isotopes and ${ }^{232} \mathrm{U}$ tracer in sea water $\left(23^{\circ} 11^{\prime} \mathrm{S} 169^{\circ} 58^{\prime} \mathrm{W}, 500 \mathrm{~m}, 51\right.$ of sea water unfiltered, $11.13 \pm 0.08 \mathrm{dpm}$ of ${ }^{232} \mathrm{U}$ was added. Counting for 1,415 $\min )$.

were added to the previous method; i.e., chromatographic separation by chelating resin which was used in the previous method was replaced by a batch method.

To each one liter of sea water, $5 \mathrm{ml}$ of $5 \% \mathrm{C}_{\mathrm{y}}$ DTA solution was added and the acidity was adjusted to $\mathrm{pH} 3$ with $6 \mathrm{M} \mathrm{HCl}$. After boiling for 10 minutes, the solution was allowed to cool to the room temperature, then it was transferred to a polyethylene bottle. $1 \mathrm{ml}$ of chelating resin was added to the solution and uranium was adsorbed on the resin under incessant mixing for 2 hours.

The resin on which uranium was adsorbed was collected into a small chromatographic column $(0.6 \mathrm{~mm}$ dia. and $10 \mathrm{~cm}$ long) followed by washing with a solution of $\mathrm{HCl}$ of $\mathrm{pH} 3$.

Uranium was subsequently eluted with $50 \mathrm{ml}$ of $5 \mathrm{M} \mathrm{HCl}$ and the effluent was evaporated to dryness. The residue was dissolved in $5 \mathrm{ml}$ of $1 \mathrm{M} \cdot \mathrm{HCl}$ and $1 \mathrm{ml}$ of 0.05\% Arsenazo-III was added. The solution was mixed and diluted to $50 \mathrm{ml}$ with distlled water. The adsorption of light by the uranium complex compound was measured at 
$650 \mathrm{~nm}$ in a cell of $100 \mathrm{~mm}$ long, 30 minutes after the addition of the reagent.

\section{Examination of analytical procedures:}

In order to find out the appropriate conditions of analysis, the duration of stirring or mixing in a batch method, a recovery and a reproducibility by the new method, and comparison of results of radiometric and spectrophotometric methods were examined.

\subsection{The adsorption of uranium on chelating resin in a batch method as a function of time:}

The relation between the duration of stirring or mixing and the rate of recovery of uranium was examined.

(a) For a sample of 4 liters: The mixture of the resin and sea water of which acidity was adjusted to $\mathrm{pH} 3$ in advance, was stirred well 【for 18 hours at the room temperature, and the amount of uranium adsorbed on the resin was determined spectrophotometrically. As shown in Fig. 2a, uranium is completely adsorbed on the resin when the stirring time exceeds 8 hours. From this result, a stirring from 10 to 15 hours was done for shipboard analysis. (b) For a sample of 1 liter: As shown in Fig. 2b, mixing longer than 2 hours is enough for the complete recovery of uranium.

The relationship between the amount of resin and the time of mixing was examined with respect to the recovery of uranium as seen in Fig. 3. It is found that an increased addition of the resin can save the time of mixing, but the amount of effluent was also increased. Therefore $1 \mathrm{ml}$ of resin per liter of sample water was regarded as an appropriate condition.

\subsection{The reproducibility and the precision of analysis:}

It is also found that the average rate of recovery of uranium by this spectrophotometric method is $100.5 \pm 2.0 \%$ as shown in Table 1. In this case, the test samples were prepared by adding a known amount of uranium to a uranium-free sea water, which was prepared by repeated ion exchange procedures. The standard deviation of analysis is below 5\% both in the radiometry and the spectrophotometry as shown in Table 2 which was obtained by analyzing three times each aliquot of the same water sample containing $2.9 \mu \mathrm{g} 1^{-1}$ of uranium.

The analytical results obtained by two

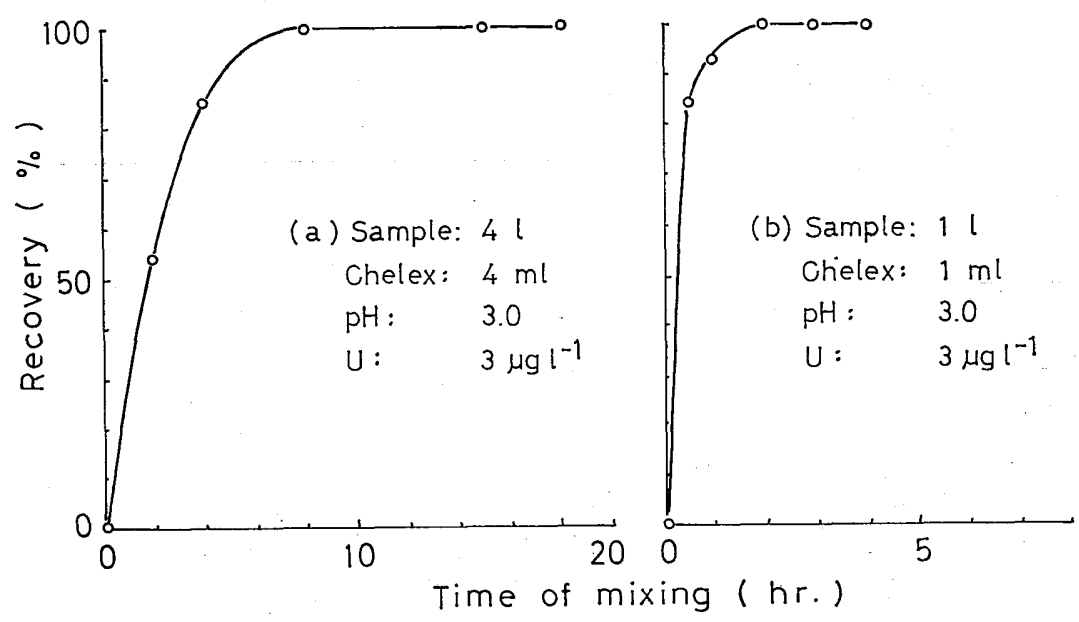

Fig. 2. Adsorption of uranium on chelating resin as a function of time of stirring or mixing. (a) 4 liters of sea water, (b) 1 liter of sea water. 
Table 1. Recovery of uranium from sea water* to which a known amount of uranium was added.

\begin{tabular}{|c|c|c|c|c|}
\hline \multirow[t]{2}{*}{ Sample No. } & \multirow{2}{*}{$\begin{array}{l}\text { Uranium added } \\
\qquad \mu \mathrm{g}\end{array}$} & \multicolumn{2}{|c|}{$\begin{array}{l}\text { Uranium found } \\
\text { Spectrophotometry }\end{array}$} & \multirow{2}{*}{$\begin{array}{l}\text { Radiometry } \\
\mu \mathrm{g}\end{array}$} \\
\hline & & $\mu \mathrm{g}$ & $\%$ & \\
\hline 1 & 1.55 & 1.59 & 102.6 & - \\
\hline 2 & 3.10 & 3.16 & 101.9 & 3.11 \\
\hline 3 & 4.65 & 4.70 & 101.1 & 4.70 \\
\hline 4 & 6.20 & 6.04 & 97.4 & 6.20 \\
\hline 5 & 7.75 & 7.73 & 99.7 & 7.75 \\
\hline $\begin{array}{l}\text { Average } \\
\text { recovery }\end{array}$ & & & $0.5 \pm 2.0$ & \\
\hline
\end{tabular}

* This water sample was free from uranium.

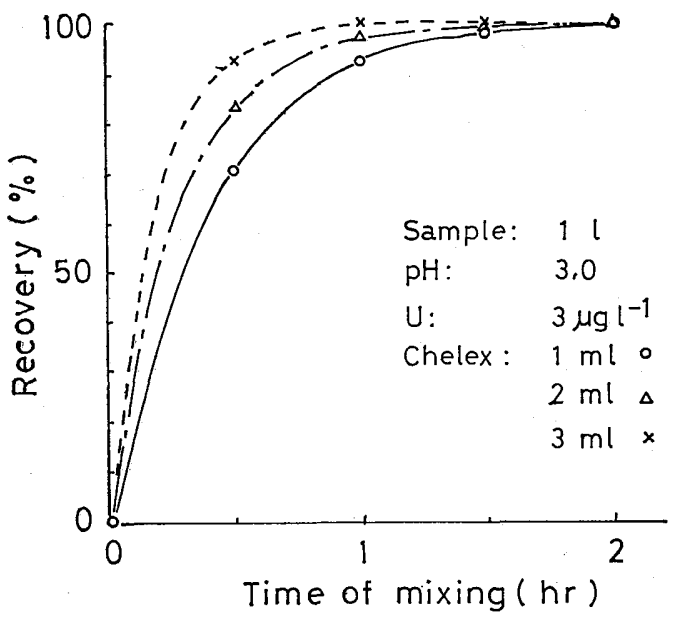

Fig. 3. Relationship between the amount of chelating resin and the time of mixing on the recovery of uranium from sea water of 1 liter.
Table 2. Reproducibility of two different methods of analysis of uranium in sea water.

\begin{tabular}{clc}
$\begin{array}{c}\text { Sample } \\
\text { No. }\end{array}$ & \multicolumn{1}{c}{$\begin{array}{c}\text { Uranium content } \\
\text { Radiometry }\end{array}$} & $\begin{array}{c}\left(\mu \mathrm{g} 1^{-1}\right) \\
\text { Spectro- } \\
\text { photometry }\end{array}$ \\
\hline 1 & $2.96 \pm 0.08(5)^{*}$ & $2.92 \pm 0.06(1)^{*}$ \\
2 & $2.95 \pm 0.08(5)$ & $2.88 \pm 0.06(1)$ \\
3 & $2.92 \pm 0.08(3)$ & $3.02 \pm 0.06(1)$ \\
\hline Average & $2.94 \pm 0.14$ & $2.94 \pm 0.11$ \\
\hline * Figure in parentheses shows volume of \\
\multicolumn{3}{l}{ sea water analyzed (liter). }
\end{tabular}

different methods were in good agreement with each other within the analytical error.

The precision of radiometric method was determined by counting the activity of uranium electroplated on a silver disk repeatedly. The result showed that the

Table 3. A comparison of analytical values of uranium content and activity ratio of ${ }^{234} \mathrm{U} /{ }^{238} \mathrm{U}$ in filtered and unfiltered sea waters.

\begin{tabular}{ccccccc}
\hline Location & $\begin{array}{c}\text { Depth } \\
(\mathrm{m})\end{array}$ & Method & Unfiltered & \multicolumn{2}{c}{$\begin{array}{c}\text { Uranium } \\
\left(\mu \mathrm{g} 1^{-1}\right) \\
\text { Filtered }\end{array}$} & $\begin{array}{c}\text { Activity ratio } \\
\left(234 \mathrm{U} /{ }^{238} \mathrm{U}\right) \\
\text { Filtered }\end{array}$ \\
\hline $42^{\circ} 02^{\prime} \mathrm{N} 143^{\circ} 33^{\prime} \mathrm{E}$ & 0 & $\mathrm{a}^{*}$ & $3.21 \pm 0.21$ & $3.30 \pm 0.12$ & $1.17 \pm 0.03$ & $1.14 \pm 0.02$ \\
$37^{\circ} 57^{\prime} \mathrm{N} 143^{\circ} 32^{\prime} \mathrm{E}$ & 0 & $\mathrm{a}$ & $3.27 \pm 0.07$ & $3.24 \pm 0.14$ & $1.13 \pm 0.03$ & $1.14 \pm 0.04$ \\
$23^{\circ} 11^{\prime} \mathrm{S} 169^{\circ} 58^{\prime} \mathrm{W}$ & 0 & $\mathrm{~b} * *$ & $3.53 \pm 0.10$ & $3.48 \pm 0.12$ & $1.16 \pm 0.03$ & $1.14 \pm 0.03$ \\
& 50 & $\mathrm{~b}$ & $3.31 \pm 0.09$ & $3.33 \pm 0.08$ & $1.19 \pm 0.03$ & $1.14 \pm 0.02$ \\
& 100 & $\mathrm{~b}$ & $3.33 \pm 0.09$ & $3.30 \pm 0.07$ & $1.13 \pm 0.03$ & $1.11 \pm 0.02$ \\
& 200 & $\mathrm{~b}$ & $3.44 \pm 0.09$ & $3.40 \pm 0.08$ & $1.15 \pm 0.03$ & $1.17 \pm 0.02$ \\
& 500 & $\mathrm{~b}$ & $3.36 \pm 0.09$ & $3.40 \pm 0.06$ & $1.14 \pm 0.03$ & $1.13 \pm 0.01$ \\
& 1000 & $\mathrm{~b}$ & $3.38 \pm 0.10$ & $3.40 \pm 0.11$ & $1.13 \pm 0.03$ & $1.12 \pm 0.03$ \\
\hline
\end{tabular}

* Spectrophotometry. ** Radiometry. 
standard deviation is below $2 \%$.

Some of the analytical results of uranium content and the isotopic ratio of ${ }^{234} \mathrm{U} /{ }^{238} \mathrm{U}$ in sea water in the western North Pacific obtained by the ihe isotope dilution method are given in Table 3 .

\subsection{The effect of filtration of water samples:}

In our previous paper (Miyake et al., 1972), it was reported that in sea water the content of uranium in suspended form was only $0.3 \%$ of the total. In the present study a comparison was done on the uranium content and isotopic ratio of ${ }^{234} \mathrm{U} /{ }^{238} \mathrm{U}$ in unfiltered and filtered samples (Millipore HA filter, $0.45 \mu \mathrm{m}$ of pore size) by using two different methods described above. The results of analysis show that there is good agreement within the analytical errors in both the uranium content and the activity ratio as shown in Table 3 , which reconfirms our previous report that most of the uranium in sea water exists in soluble form (particle size smaller than $0.45 \mu \mathrm{m}$ ). It is to be noted that similar results were reported recently by Spencer et el. (1970) and $\mathrm{Ku}$ et al. (1977) in water samples collected in the Pacific and the Atlantic Oceans respectively.

\section{References}

Kim, S. M., J.E. Noakes and W.W Miller (1966) : Electro-deposition method for counting alpha and beta emitters. Nucleonics, 24, 66-77.

Ku, T.L., K. G. Knauss and G. G. Mathieu (1977) : Uranium in open occean: concentration and isotopic composition. Deep-Sea Res., 24, 10051017.

Miyake, Y., Y. Sugimura and T. Uchida (1966): Ratio ${ }^{234} \mathrm{U} /{ }^{238} \mathrm{U}$ and the uranium concentration in sea water in the western North Pacific. J. Geophys. Res., 71, 3083-3087.

Miyake, Y., Y. Sugimura and M. Mayeda (1970) : The uranium content and the activity ratio ${ }^{234} \mathrm{U} /{ }^{238} \mathrm{U}$ in marine organisms and sea water in the western North Pacific. J. Oceanogr. Soc. Japan. 26, 123-129.

Miyake, Y., Y. Sugimura and, T. Uchida (1972) : A new method of spectraphotometric determination of uranium in sea water and uranium content with ${ }^{234} \mathrm{U} /{ }^{238} \mathrm{U}$ ratio in the Pacific water. Rec. Oceanegr. Wks. Japan. 11, 53-63.

Spencer, D. W., D. E. Robertson, K. K. Turekian and T.R. Folsom (1970): Trace element calibrations and profiles at the Geosecs test station in the Northeast Pacific Ocean. J. Geophys. Res., 75, 7688-7696.

\section{キレート樹脂を使用する海水中のウラン分析法 一改良法一}

\section{杉村行勇・前田 勝*}

著者らはすでと海水中のウラン分析法として，キレート樹脂を用いるカラム法による分析法を開発し，それを用 いて多くの研究を行なった。本報は，船上分析や，大量の海水処理に便利なように，バッチ法による改良法を検討 したのでその結果を述べる。海水 1 〜 51 をビーカーにとり， pH 3 に調整したのち，キレート樹脂を添加し，攪 找してウランを吸着分離する。ウランの定量には $\alpha$ 同位体希釈法をたは分光光度法を用いる。この方法による平均 回収率は100\%で，カラム法による分析結果とよく一致している。本方法は，船上においてもまた実験室に和いて も，カラムの目づまりなどを考虑することなく簡便に使用できることが明らかになった。

*東京水産大学環境科学科 